https://doi.org/10.15421/40280402

Article received 13.04.2018 p.

Article accepted 26.04.2018 p.

удк 330.[342+725.2]
$@ \bowtie$ Correspondence author Ya. V. Kul'chyts'kyj kulchytskyj.b@ukr.net

Я. В. Кульчицький1 , Б. В. Кульчицький', М. В. Маліновська 1

${ }^{1}$ Національний лісотехнічний університет Украӥни, м. Львів, Україна

${ }^{2}$ Львівський національний університет ім. Івана Франка, м. Львів, Україна

\title{
ЕКОЛОГІЗАЦІЯ ЕКОНОМІЧНИХ СИСТЕМ ЯК ПРІОРИТЕТ ЇХ ТРАНСФОРМАЦІЇ У ХХІ СТОЛІТТІ
}

Розкрито інституційні засади екологізації сучасних економічних систем з позицій постіндустріальної парадигми та економічної компаративістики в умовах посилення глобалізації. Наведено зміст екологічної парадигми економічної теорії та обгрунтовано потреба виокремлення соціально-екологічних відносин у системі економічних відносин суспільства. Підкреслено важливість формування сучасної екологічної культури у процесі трансформації економічних систем, коли в їі основі мають бути орієнтованість на екологічну доцільність і безпеку, відсутність протиставлення людини і природи. Запропоновано авторське трактування процесу екологізації сучасних економічних систем в умовах посилення глобалізації, переходу людства до суспільства знань та "зеленої економіки". Під екологізацією економічних систем пропонуємо розуміти посилення екологічної спрямованості економічних систем у процесі їх трансформації, що виявляється у становленні сучасної економічної та екологічної свідомості і культури, екологічної відповідальності, утвердженні сучасних екологічних цінностей, формуванні відповідної нормативно-правової, інституційної бази, спрямованої на суспільний контроль за системою зв'язків "людина - економіка - екологія", застосуванні санкцій і стимулів щодо впливу економічної системи на стан екологічної рівноваги в умовах обмеженості природних ресурсів та посилення екологічної кризи глобального, регіонального і локального характеру. Екологізація економічних систем є об'єктивним процесом їх трансформації, домінантою трансформації на зламі тисячоліть, що утверджує усвідомлення екологічних проблем як глобальних. Екологізацію економічних систем розглядають сьогодні як дуже важливий, навіть визначальний, критерій порівняльного аналізу національних систем чи наднаціональних системних утворень. Запропоноване поняття "екологізація економічних систем", на наше переконання, не тільки заповнює відповідну прогалину в економічній теорії, а й дає змогу повністю врахувати екологічний контекст дослідження і порівняння економічних систем на порозі третього тисячоліття.

Ключові слова: економічні системи; екологічна парадигма економічної теорії; економічна компаративістика; стійкий розвиток; екологізація економічних систем.

Вступ. Дослідження сучасних економічних систем об'єктивно передбачає виявлення пріоритетних домінант їх трансформації, якими у XXI ст. є, на наш погляд, екологізація та глобалізація. Саме ці процеси здійснюють нині вирішальний вплив на функціонування і трансформацію існуючих чи становлення нових економічних систем. Будучи щільно взаємопов'язаними, вони зумовлюють ключові параметри економічних систем, їх елементну структуру, визначають найважливіші функції. I хоча актуальність проблеми екологізації економіки не підлягає сумніву, проте більшість існуючих наукових досліджень мають або виключно економічний, прагматичний ухил, або природоохоронну спрямованість у чистому вигляді. Звідси випливає потреба комплексного підходу до цієї складної й надзвичайно важливої теоретичної і практичної проблеми на основі діалогу економічної та інших наук.

Метою роботи є розроблення теоретико-методологічних засад дослідження і з'ясування змісту екологізації сучасних економічних систем у контексті економіч- ної компаративістики, утвердження екоцентристської системи цінностей, ідеї так званої "зеленої економіки", відповідної екологічної свідомості та культури, що має важливе значення не тільки для методології економічної теорії, а й також практики державного регулювання взаємодії економічної та екологічної систем, забезпечення стійкого розвитку як розвинених, так і транзитивних, перехідних економічних систем в умовах посилення глобалізаційних процесів.

Методами дослідження є насамперед діалектичний, історичний, логічний, системний, синергетичний, порівняльного, сценарного аналізу, міждисциплінарний та ін.

Ступінь розроблення проблеми та огляд літератури. Варто підкреслити, що незважаючи на актуальність проблеми екологізації сучасних економічних систем як пріоритету їх трансформації в умовах епохального переходу людства до інформаційного (постіндустріального за історичною суттю), "знаннєвого" суспільства, науковці часто по-різному тлумачать цю проблеми. Тому намагатимемось проаналізувати основні під-

\section{Інформація про авторів:}

Кульчицький Ярослав Володимирович, д-р екон. наук, професор, кафедра економічної теорії. Email: kulchytskyj.b@ukr.net Кульчицький Богдан Володимирович, д-р екон. наук, професор, кафедра економічної теорії. Email: kulchytskyj.b@ukr.net Маліновська Мирослава Володимирівна, асистент, кафедра економічної теорії. Email: kulchytskyj.b@ukr.net Цитування за ДСтУ: Кульчицький Я. В., Кульчицький Б. В., Маліновська М. В. Екологізація економічних систем як пріоритет їх трансформації у XXI столітті. Науковий вісник НЛтУ України. Серія Економічна. 2018, т. 28, № 4. С. 15-19

Citation APA: Kulchytskyj, Ya. V., Kulchytskyj, B. V., \& Malinovska, M. V. (2018). An Ecologization of the Economic Systems as Priority of Their Transformation in XXI Century. Scientific Bulletin of UNFU, 28(4), 15-19. https://doi.org/10.15421/40280402 
ходи до іiі вирішення та обгрунтувати власну наукову концепцію.

У процесі взаємодії суспільство і природа постійно впливають одне на одного. Але міра такого взаємовпливу не є незмінною. Економічно-історичний розвиток передбачає збільшення знань і удосконалення засобів i способів людської діяльності, що робить вплив суспільства на природу дедалі вагомішим і помітнішим. Цей вплив має свої певні особливості. Насамперед, він здійснюється 3 метою покращення умов людського життя і задоволення зростаючих потреб на стихійній і свідомій, планомірній основі (Kulchytskyi, Kulchytskyi \& Dzhyhora, 2016; Kulchytskyi, et. al., 2017a). Головним способом цілеспрямованого впливу суспільства на природу з метою задоволення його потреб і $є$, на нашу думку, економічна діяльність, що виступає у цьому випадку у формі екологічної діяльності (Kulchytskyi \& Kulchytskyi, 2015, pp. 257-258; Kulchytskyi, 2011, pp. 239; Kulchytskyi, 2017, pp. 68). При цьому екологічна діяльність $є$ усвідомленою соціальною активністю, безпосередньо спрямованою на перетворення довкілля (Kulchytskyi, 2003, 2005). На наш погляд, екологічна діяльність як невід'ємний складник цілісної людської діяльності, що безпосередньо спрямований на свідоме перетворення навколишнього середовища, 3 розвитком НТП, зростанням значення антропогенного чинника на подальшу долю Всесвіту відіграє дедалі вагомішу роль у визначенні структури, функцій і стратегічного вектора трансформації сучасних економічних систем (Kulchytskyi \& Kulchytskyi, 2007; Kulchytskyi, 2008; Kulchytskyi, et. al., 2017b).

Дослідження економічної діяльності на початку третього тисячоліття в умовах посилення процесу екологізації сучасних економічних систем зумовлює, на наше глибоке переконання, потреба перегляду, переосмислення фундаментальних методологічних постулатів, положень економічної теорії (Kulchytskyi \& Kulchytskyi, 2015, pp. 259; Kulchytskyi, 2017, pp. 68). Економічна теорія протягом своєї тисячолітньої еволюції пройшла багато етапів розвитку. При цьому, зрозуміло, видозмінювався предмет ii наукового аналізу, методологія, теоретичні парадигми та концепти, що зумовлювало відповідні зміни економічного дискурсу, коригувало стратегію фундаментальних досліджень. Але завжди підгрунтям наукових концепцій, висновків, рекомендацій були реальні економічні процеси, суспільна економічна практика, яка виступає єдиним i визначальним критерієм істинності теорії. Початок XXI ст. ознаменувався новим злетом української та світової економічної науки, іiі активним діалогом з багатьма іншими науками: від соціально-філософських до природничих. Практичними причинами таких тенденцій у методології економічної теорії стали насамперед нагальні проблеми взаємин людини і довкілля, потреба екологізації економічних систем (Kulchytskyi \& Kulchytskyi, 2015, pp. 259).

Внаслідок цих негативних тенденцій в економічній теорії міцно почала утверджуватися екологічна парадигма, що передбачає розгляд усіх економічних і соціальних процесів крізь призму збереження довкілля, умов існування і розвитку людської особистості (Kulchytskyi \& Kulchytskyi, 2015, pp. 258-259; Kulchytskyi, 2011, pp. 240-241; Kulchytskyi, 2003, 2005,
2008; Kulchytskyi, et. al., 2017b; Kulchytskyi, 2017, pp. 68-69). Як обгрунтовано зазначають у цьому контексті сучасні польські дослідники Б. Фєдор, С. Чая, А. Грачик, 3. Якубчик, екологічна парадигма економічної теорії виростає насамперед 3 критики можливостей традиційного неокласичного оптимізаційного аналізу до вирішення проблеми деградації та охорони довкілля, а також забезпечення відповідної його якості і доступності природних засобів для майбутніх поколінь. Ця критика спирається на такі аргументи, як: по-перше, багатовимірність явищ, що перебувають на "стику" економічної системи і довкілля; по-друге, взаємозалежність між економічною системою, з одного боку, і природними системами (фізична, біологічна, метеорологічна та ін.), з іншого (Fiedor, et. al., 2012, pp. 22).

На думку Ю. Туниці, між традиційною ринковою економікою та екологічними вимогами існують глибокі суперечності. Тому головною проблемою сучасної економічної науки повинно стати формування нової екологічної економіки: "Наука повинна зробити все можливе для адаптації ринкової моделі економіки до вимог екологічної економіки, більше того, в реальному житті повинна відбутися трансформація ринкової економіки в екологічну" (Tunytsia, 2006, pp. 21). Учений слушно вважає, що економічна наука на початку третього тисячоліття мусить змінити або принаймні істотно уточнити свою парадигму, оскільки "предмет класичної і неокласичної економіки стає ширшим і складнішим з огляду на розширення поняття третього фактора виробництва "природні ресурси" до поняття "природне довкілля" (environment)" (Tunytsia, 2006, pp. 26-27).

Сучасні, найбільш досконалі, зарубіжні підручники з економічної теорії (зокрема, авторства К. Макконнела i C. Брю) недостатньо враховують екологічний імператив, бо потрібно досліджувати поведінку людей у процесі виробництва, розподілу і споживання матеріальних благ та послуг не просто в умовах обмежених ресурсів, а вже в нових умовах - умовах загострення екологічної кризи глобального, регіонального і локального характеру. На думку вченого, йдеться про істотні зміни предмету економіки, або ж формування поруч з класичною i неокласичною економічною теорією нової еколого-економічної теорії чи екологічної економіки, яка є, з одного боку, продуктом розвитку економічної думки в історичній ретроспективі і спирається на досягнення новітньої економічної теорії, а 3 іншого - результатом спостережень та аналізу розвитку сучасного світу, його природи і суспільства, результатом аналізу цілком нових екологічних проблем (Tunytsia, 2006, pp. 26-29). Загалом Ю. Туниця наголошує: "3 одного боку, екологічна економіка є складовою частиною економічної теорії, 3 іншого - вона вимагає докорінної зміни сутності й змісту економічних наук щодо відображення ними екологічного імперативу..." (Tunytsia, 2006, pp. 83).

Ми повністю погоджуємося з Ю. Туницею, який виводить екологічну економіку з економічної теорії і вважає іiї складовою останньої. Справді, яким би не був жвавим діалог економічної та інших наук, але оновлена й збагачена сучасними концептами та постіндустріальною парадигмою економічна теорія $є$ саме тим методологічним фундаментом, річищем, у руслі якого виокремлюється екологічна економіка як віддзеркалення об'єктивного процесу утвердження екологічного імпе- 
ративу саме в економічній теорії. Підсумовуючи роздуми про екологічний імператив у новітній економічній теорії, учений аргументовано наголошує, що "...повинна відбуватися екологізація економічної теорії та інших економічних дисциплін i, водночас, економізація екології та інших природничих дисциплін" (Tunytsia, 2006, pp. 84).

Об'єктивні зміни, що відбуваються нині у розвинених економічних системах, повинні, на наше переконання, знайти відображення у теоретичному виокремленні соціально-екологічних відносин у системі економічних відносин суспільства. При цьому ми вважаємо, що під соціально-екологічними відносинами потрібно розуміти відносини, які об'єктивно складаються між суб'єктами економічної системи суспільства, екологоекономічної діяльності у процесі свідомого перетворення природного світу на основі відповідної економічної та екологічної культури (Kulchytskyi \& Kulchytskyi, 2015, pp. 266; Kulchytskyi, 2011, pp. 240-318; Kulchytskyi, 2005, pp. 105-121; Kulchytskyi, 2003, 2008; Kulchytskyi \& Kulchytskyi, 2007, pp. 54-58).

Цей підхід справді дав би змогу не тільки зосередити увагу вчених-теоретиків на розкритті змісту й місця соціально-екологічних відносин у поняттєвому апараті економічної теорії, але й спонукати до всебічного вивчення особливостей функціонування цих відносин у сучасних розвинених економічних системах 3 метою їх максимального врахування в економічній та екологічній політиці країн з перехідними економічними системами у процесі їх трансформації в умовах посилення екологізації та глобалізації.

Стверджуючи нагальність засвоєння суспільною свідомістю екоцентристської системи цінностей та настанов, ми 3 необхідністю доходимо висновку про усвідомлення важливості екологічної культури у процесі становлення i трансформації економічних систем (Kulchytskyi \& Kulchytskyi, 2015, pp. 275-280; Kulchytskyi, 2005, 2008; Kulchytskyi \& Kulchytskyi, 2007, pp. 64-65). У підгрунтя формування сучасної екологічної культури потрібно покласти насамперед орієнтованість на екологічну доцільність і безпеку, відсутність протиставлення людини і природи, сприйняття природних об'єктів як повноправних партнерів у взаємодії з людиною (Kulchytskyi \& Kulchytskyi, 2015, pp. 278-279).

Висновки. Проведений аналіз теоретико-методологічних підходів до визначення змісту екологізації економічних систем як пріоритету їх трансформації у XXI ст. засвідчив складність і навіть суперечливість відповідних наукових пошуків. Власне, зважаючи на відсутність одностайності у розумінні й тлумаченні цього дуже важливого планетарного процесу, ми вважали за необхідне обгрунтувати свій концептуальний підхід до розуміння природи й змісту екологізації економічних систем в умовах значного посилення глобалізації, епохального переходу людства до інформаційного, "знаннєвого" суспільства та "зеленої економіки".

На наше переконання, дослідження і порівняння сучасних економічних систем повинні бути щільно пов'язані з аналізом процесів екологізації та генези постіндустріального, інформаційного суспільства та суспільства, заснованого на знаннях. Екологізацію потрібно розглядати як новий контекст, визначальний крите- рій дослідження і порівняльного аналізу економічних систем. При цьому розкриття змісту процесу екологізації $є$ насамперед можливістю по-новому підійти до порівняння сучасних економічних систем, адже одними 3 найважливіших для оцінки просування економічної системи до нової якості життя суспільства є параметри, показники, що характеризують міру вирішення саме екологічних проблем. Окрім цього, як ми зазначали вище, подолання світової екологічної кризи потребує нині об'єднання зусиль різних країн, усього світового співтовариства. Водночас дослідження "екологічного" профілю тієї чи іншої конкретної економічної системи неминуче призводить нас до необхідності урахування глобального аспекту функціонування системи в контексті iii "участі" у забрудненні довкілля у планетарному масштабі чи, наприклад, вивезенні "брудних" технологій у відсталі країни, коли йдеться про розвинуті економічні системи.

Отже, подальший розвиток економічної теорії та обгрунтування теоретико-методологічних засад порівняльного аналізу сучасних економічних систем потребують комплексного, взаємопов'язаного бачення проблем екологізації і трансформації економічних систем крізь призму глобалізації процесів інституціоналізації представниками різних галузей наукового знання. Іншими словами, йдеться про потреба об'єднання зусиль на "стиках" наук про людину і суспільство. Власне, зважаючи на певну відособленість, автономність наукових досліджень екологічних проблем, з одного боку, та досліджень сучасних економічних систем, - 3 іншого боку, а також враховуючи діалектичну єдність, нерозривність і глибинну взаємозалежність, взаємозумовленість довкілля, природи, екосистеми та економічної системи, вважаємо за доцільне запровадити до наукового обігу поняття "екологізація економічних систем".

Під екологізацією економічних систем пропонуємо розуміти посилення екологічної спрямованості економічних систем у процесі їх трансформації, що виявляється у становленні сучасної економічної та екологічної свідомості і культури, екологічної відповідальності, утвердженні сучасних екологічних цінностей, формуванні відповідної нормативно-правової, інституційної бази, спрямованої на суспільний контроль за системою зв'язків "людина - економіка - екологія", застосуванні санкцій і стимулів щодо впливу економічної системи на стан екологічної рівноваги в умовах обмеженості природних ресурсів та посилення екологічної кризи глобального, регіонального і локального характеру. Екологізація економічних систем є об'єктивним процесом їх трансформації, домінантою трансформації на зламі тисячоліть, що утверджує усвідомлення екологічних проблем як глобальних. Екологізацію економічних систем розглядають сьогодні як дуже важливий, навіть визначальний, критерій порівняльного аналізу національних систем чи наднаціональних системних утворень.

Запропоноване поняття "екологізація економічних систем", на наше переконання, не тільки заповнює відповідну прогалину в економічній теорії, а й дає змогу повністю врахувати екологічний контекст дослідження і порівняння економічних систем на порозі третього тисячоліття. При цьому хочемо підкреслити, що "екологізація економічних систем" - це не просто екологізація 
економіки шляхом застосування санкцій, штрафів, обмежень і т. ін., а насамперед докорінні зміни на рівні панівних екологічних та економічних суспільних цінностей, інституцій. Тільки такий складний, тривалий у часі, але, очевидно, безальтернативний підхід може забезпечити розвиток як національних, так і світової економічних систем, відповісти на виклики цивілізаційного поступу у XXI ст.

\section{Перелік використаних джерел}

Fiedor, B. (Ed.), Czaja, S., Graczyk, A., \& Jakubczyk, Z. (2012). Podstawy ekonomii środowiska i zasobów naturalnych. Warszawa: Wydawnictwo C. H. Beck. 484 p.

Kulchytskyi, Ya. V. (2003). Ekoloho-ekonomichni systemy (problemy teorii i metodolohii doslidzhennia). Lviv: UkrDLTU. 64 p. [In Ukrainian].

Kulchytskyi, Ya. V. (2005). Problemy formuvannia sotsialno-ekolohichnykh suspilnykh vidnosyn u konteksti transformatsii suchasnykh ekoloho-ekonomichnykh system: monohrafiia. Lviv: Kamula. 144 p. [In Ukrainian].

Kulchytskyi, Ya. V. (2008). Ekolohizatsiia ekonomichnykh system u konteksti postindustrialnoho paradyhmalnoho dyskursu ta ekonomichnoi komparatyvistyky. Rehionalna ekonomika, 1, 77-84. [In Ukrainian].

Kulchytskyi, Ya. V. (2011). Suchasni ekonomichni systemy v umovakh ekolohizatsii ta hlobalizatsii (teoretyko-metodolohichni zasady porivniannia): monohrafiia. Lviv: Liha-Pres. 687 p. [In Ukrainian].

Kulchytskyi, Ya. V. (2017). Formuvannia ekolohichnoi svidomosti ta kultury pid chas vykladannia ekonomichnykh dystsyplin. Ekolohi- zatsiia osvity yak chynnyk staloho rozvytku suspilstva: mater. Mizhnar. nauk.-prakt. konf., (pp. 68-71) Lviv: RVV NLTU Ukrainy. 420 p. [In Ukrainian].

Kulchytskyi, Ya. V., \& Kulchytskyi, B. V. (2007). Porivniannia ekonomichnykh system (problemy metodolohii): monohrafiia. Lviv: Vyd. tsentr LNU imeni Ivana Franka. 318 p. [In Ukrainian].

Kulchytskyi, Ya. V., \& Kulchytskyi, B. V. (2015). Filosofiia ekonomichnykh system (rozvytok metodolohii yikh porivnialnoho analizu $v$ umovakh ekolohizatsii, intelektualizatsii ta hlobalizatsii): monohrafiia. Lviv: Liha-Pres. 710 p. [In Ukrainian].

Kulchytskyi, Ya. V., Kulchytskyi, B. V., \& Dzhyhora, N. V. (2016). Instytutsiini zasady traktuvannia ekonomichnykh system $\mathrm{v}$ umovakh posylennia yikh ekolohizatsii ta hlobalizatsii. Scientific Bulletin of UNFU. Economical series, 26(6), 7-13. Lviv: RVV NLTU Ukrainy. [In Ukrainian].

Kulchytskyi, Ya. V., Kulchytskyi, B. V., Bashnianyn, H. I. (Ed.) \& Osetskyi, V. L. (2017a). Filosofiia ekonomichnykh system u konteksti hnoseolohii suspilno-ekonomichnykh transformatsii. Ekonomichni systemy: monohrafiia. Vol. 6, (pp. 60-96). Lviv: Liha-Pres. 360 p. [In Ukrainian].

Kulchytskyi, Ya. V., Kulchytskyi, B. V., Bashnianyn, H. I. (Ed.) \& Osetskyi, V. L. (2017b). Instytutsiinyi pidkhid do traktuvannia ekonomichnykh system za umov posylennia yikh ekolohizatsii ta hlobalizatsii. Systemnyi analiz ekonomichnykh system: zb. nauk. prats za mater. Druhoho Vseukr. kruhloho stolu, (pp. 9-15). Lviv: LihaPres. 382 p. [In Ukrainian].

Tunytsia, Yu. Yu. (2006). Ekoekonomika i rynok: podolannia superechnostei. Kyiv: Znannia. 314 p. [In Ukrainian].

Я. В. Кульчицкий1', Б. В. Кульчицкий', М. В. Малиновская 1

${ }^{1}$ Начиональный лесотехнический университет Украины, г. Львов, Украина

2 Львовский национальный университет им. Ивана Франко, г. Львов, Украина

\section{ЭКОЛОГИЗАЦИЯ ЭКОНОМИЧЕСКИХ СИСТЕМ КАК ПРИОРИТЕТ ИХ ТРАНСФОРМАЦИИ В ХХІ ВЕКЕ}

Раскрыты институциональные принципы экологизации современных экономических систем с позиций постиндустриальной парадигмы и экономической компаративистики в условиях усиления глобализации. Приведено содержание экологической парадигмы экономической теории и обоснована необходимость выделения социально-экологических отношений в системе экономических отношений общества. Подчеркнута важность формирования современной экологической культуры в процессе трансформации экономических систем, когда в ее основе должны быть ориентированность на экологическую целесообразность и безопасность, отсутствие противопоставления человека и природы. Предложена авторская трактовка процесса экологизации современных экономических систем в условиях усиления глобализации, перехода человечества к обществу знаний и "зеленой экономики". Под экологизацией экономических систем предлагаем понимать усиление экологической направленности экономических систем в процессе их трансформации, которая оказывается в становлении современного экономического и экологического сознания и культуры, экологической ответственности, утверждении современных экологических ценностей, формировании соответствующей нормативно-правовой, институциональной базы, направленной на общественный контроль за системой связей "человек - экономика - экология", применении санкций и стимулов относительно влияния экономической системы на состояние экологического равновесия в условиях ограниченности природных ресурсов и обострения экологического кризиса глобального, регионального и локального характера. Экологизация экономических систем является объективным процессом их трансформации, доминантой трансформации на изломе тысячелетий, который утверждает осознание экологических проблем как глобальных. Экологизация экономических систем рассматривается сегодня как очень важный, даже определяющий, критерий сравнительного анализа национальных систем или наднациональных системных образований. Предложенное понятие "экологизация экономических систем", по нашему убеждению, не только заполняет соответствующий пробел в экономической теории, но и дает возможность полностью учесть экологический контекст исследования и сравнения экономических систем на пороге третьего тысячелетия.

Ключевые слова: экономические системы; экологическая парадигма экономической теории; экономическая компаративистика; устойчивое развитие; экологизация экономических систем.

Ya. V. Kul'chyts'kyj ${ }^{1}$, B. V. Kul'chyts'kyj2, M. V. Malinovs'ka' ${ }^{1}$ Ukrainian National Forestry University, Lviv, Ukraine

${ }^{2}$ Ivan Franko National University of Lviv, Lviv, Ukraine

\section{AN ECOLOGIZATION OF THE ECONOMIC SYSTEMS AS PRIORITY OF THEIR TRANSFORMATION IN XXI CENTURY}

Institutional principles of ecologization of the modern economic systems are exposed from positions of post-industrial paradigm and comparisons of economic systems in the conditions of strengthening of globalization. Maintenance of ecological paradigm of economic theory is educed and the necessity of selection of social-and-ecological relations is reasonable for the system of economic relations of society. The importance of forming of modern ecological culture is underlined in the process of transformation of the economic systems, which should be oriented towards ecological expediency and safety, and also absence of contrasts between man 
and nature. Authors' interpretation offers the process of ecologization of the modern economic systems in the conditions of globalization strengthening, transition of humanity to the society of knowledge and "green economy". We suggest to understand ecologization of the economic systems as strengthening of their ecological orientation in the process of transformation, which means formation of modern economic and environmental consciousness and culture, environmental responsibility, affirmation of modern environmental values, forming of proper normatively-legal, institutional base, under the public inspection of the system of connections "man - economy - ecology", application of approvals and stimuli concerning influence of the economic system on the state of ecological equilibrium in the conditions of the limited natural resources and intensifying of ecological crisis of global, regional and local character. Ecologization of the economic systems is the objective process of their transformation, by the dominant of transformation on the fracture of millenniums, which asserts realization of ecological problems at global scale. Today we consider ecologization of the economic systems to be a very important, even crutial criterion of comparative analysis of the national systems or international system educations. We believe the offered concept of ecologization of the economic systems both to fill a corresponding gap in an economic theory and enable fully to take into account the environmental context of research and comparison of the economic systems on the threshold of the third millennium.

Keywords: economic systems; environmental paradigm of economic theory; comparative analysis of the economic systems; sustainable development; ecologization of the economic systems. 